\title{
Gastric Teeth of Some Thoracotreme Crabs and Their Contribution to the Brachyuran Phylogeny
}

\author{
Andreas Brösing* and Michael Türkay \\ Senckenberg Forschungsinstitut und Naturmuseum, Senckenberganlage 25, 60325 Frankfurt, Germany
}

\begin{abstract}
The gastric teeth of three ocypodoid species were investigated using scanning electron microscopy, and the morphological results were discussed with respect to the known food preferences. The species were chosen in particular because of contrasting ideas about their relationships within the Thoracotremata. For the genera $\mathrm{Hel}$ oecius, Dotilla, Mictyris, and "Uca" (s. str.), we find a specific correlation of the gastric teeth with the suspension feeding. The lateral gastric teeth of Uca have no prominent lateral teeth cusps, and most of their teeth surface consists of transverse comb-like lamellae. However, this possible food adaptation does not exclude the usability of specific teeth characters to distinguish species of suspension feeders. The closer relationship of the Dotillidae to grapsoid lines of gecarcinid or sesarmid crabs suggested by molecular data is not supported by the gastric teeth. For the genus Ucides, we found several characters that distinguish Ucides from the remaining ocypodoid genera Heloecius, Dotilla, Mictyris, and "Uca." In particular, the structures of the lateral and the dorsomedian teeth show some similarities to genera of the Gecarcinidae and Sesarmidae. Our results suggest that foregut characters can be used for phylogenetic analyses. J. Morphol. 272:11091115, 2011. (c) 2011 Wiley-Liss, Inc.
\end{abstract}

KEY WORDS: gastric teeth; ocypodoidea; grapsoidea; SEM

\section{INTRODUCTION}

During the last decade, new morphological characters such as the foregut structures (gastric teeth and foregut ossicles) have been introduced into brachyuran phylogenetic discussions. Their morphology is receiving increasing attention as a valuable character complex to separate brachyuran taxa of different ranks (Sakai et al., 2006; Brösing et al. 2007; Huespe et al., 2008; Allardyce and Linton, 2010; Alves et al., 2010; Brösing, 2010; Naderloo and Schubart, 2010).

The foregut of brachyuran decapods is divided into two regions: the cardiac foregut with the oesophagus and the pyloric foregut. The anterior portion of the cardiac foregut is a thin-walled, noncalcified, sack-shaped structure. It is stretched between several cardiac ossicles and cardiac plates. Some of these cardiac ossicles bear teeth, forming the chewing apparatus of the gastric mill. The posterior portion of the cardiac foregut and the pyloric foregut are supported and strengthened by a number of small pyloric ossicles and plates (Maynard and Dando, 1974; Meiss and Normann, 1977; Felgenhauer, 1992; Ceccaldi, 1997; Brösing 2002; Brösing et al., 2002; Brösing, 2010). In contrast to the outer mouthparts, the teeth of the gastric mill are mainly responsible for crushing and cutting ingested food particles.

A correlation of the foregut structures with described food preferences and their usability for phylogenetic reconstructions in decapods have been discussed by several authors within the last decades, especially in relation to anomuran crabs (Caine, 1975), parastacid crayfish (Growns and Richardson, 1990), lower decapods (Abele and Felgenhauer, 1986; Felgenhauer and Abele, 1983, 1985, 1989), and brachyuran crabs (Crane, 1975; Kropp, 1986; Yang, 1986; Sakai et al., 2006; Brösing et al., 2007). These authors concluded that the gastric mill is more affected by phylogeny that by the animals' diet. This conclusion is strongly supported the observation that the phylogenetic groups built on gastric mill morphology are the same as those built on the examination of other phylogenetically important characters, such as the gonopods (e.g., Sakai et al., 2006).

This article focuses on the gastric teeth of a set of selected thoracotreme species that has been placed in different families in the past. Species selection has been made to contribute to the ongoing phylogenetic discussions as to the classification of the Ocypodoidea and Grapsoidea.

\section{MATERIAL AND METHODS Animals}

Animals used in this study are listed in Table 1.

\footnotetext{
*Correspondence to: Andreas Brösing, Senckenberg Forschungsinstitut und Naturmuseum, Senckenberganlage 25, 60325 Frankfurt, Germany. E-mail: abroesing@senckenberg.de
}

Received 6 December 2010; Revised 14 February 2011;

Accepted 12 March 2011

Published online 31 May 2011 in

Wiley Online Library (wileyonlinelibrary.com)

DOI: 10.1002/jmor.10967 
TABLE 1. Investigated species

\begin{tabular}{lclc}
\hline \multicolumn{1}{c}{ Species } & Catalog Number & \multicolumn{1}{c}{ Location } & CW/CL (mm) \\
\hline Dotilla fenestrata (Hilgendorf, 1869) & SMF 9109 & Kenja, Küste, S. Malindi, Mida-Creek, & 11/9 \\
& & Insel, Mangrove, Okt. 1979, leg Grasshoff & No locality data available \\
Ucides occidentalis (Ortmann, 1897) & SMF 4139 & Australien, Queensland, Jacobs Well ca. & 66/45 \\
Heloecius cordiformis & SMF 921 & 50 km S. Brisbane, Salzwiese, & 30. V. 1980, leg. M. Türkay \\
(H. Milne Edwards, 1837) & & & \\
& &
\end{tabular}

\section{Methods}

Gastric teeth of $70 \%$ ethanol-preserved specimens were dissected using a stereo microscope (LEICA MZ8) and prepared for scanning electron microscopy according to Brösing et al. (2002). For scanning electron microscopy, we used AC digital scanning electron microscope (CamScan, Elektronenoptik $\mathrm{GmbH}$ ) at the Senckenberg Forschungsinstitut und Naturmuseum, Frankfurt.

\section{RESULTS \\ Gastric Teeth of Dotilla fenestrata}

The lateral teeth are characterized by an anterolateral straight margin without teeth cusps on the first two-thirds of the lateral teeth. The posterolateral third of the lateral teeth has three to four small teeth cusps (Fig. 1A). The median margin consists of 19 transverse comb-like lamellae (Fig. 1A,B). The urocardiac ossicle (VII), carrying the dorsomedian tooth, has a triangular shape and widens at the posterior end. The dorsomedian tooth at the posterior quarter of the ossicle consists of two transverse teeth cusps. The anterior and lateral margins of the first quarter of the urocardiac ossicle have a row of setose hairs (Fig. 1C). Antero-laterally, with respect to the lateral gastric teeth there are at least 14 long extended pointed accessory teeth (Fig. 1D). The cardio-pyloric valve has antero-dorsally a remarkable single tooth cusp surrounded by brush-like setae (Fig. 1E). Its dorsal surface is trapezoidally shaped, with one pair of posteriorly directed, long bristles and one pair of laterally fringed bulges (Fig. 1F).

\section{Gastric Teeth of Ucides occidentalis}

The lateral gastric teeth have well-developed and transversally arranged tooth cusps and become smaller toward the anterior. The transverse cusps of the posterior half have small anteriorly directed comb-like processes as in Heloecius (Fig. 2A,B). The dorsomedian tooth consists of 12 transverse tooth cusps, becoming smaller toward the anterior (Fig. 2C). Anterolaterally with respect to the lateral gastric teeth are situated 15 accessory teeth with lancet-shaped tips (Fig. 2D). The cardiopyloric valve is dorsally triangular with bristles on its posterodorsal margin and an anterodorsal single strong median tooth (Fig. 2E). The anterior margin of the cardiopyloric valve is covered by brush-like setae (see also Fig. 2E). Furthermore, the dorsolateral margin has a pair of laterally fringed bulges as in Dotilla (Fig. 2F).

\section{Gastric Teeth of Heloecius cordiformis}

The lateral gastric teeth are oval-shaped and lack raised tooth cusps. Most of the 22 transverse lamellae consist of small, comb-like processes pointing toward the anterior (Fig. 3A,B). The lamellae of the posterior half of the lateral teeth end mid-laterally in a bunch of elongated bristles. The anterior third of the dorsomedian tooth is oval-shaped, followed posteriorly by a pair of wing-like plates, which are connected in the midline and elongated toward the posterior third. The remaining dorsomedian toothstructure looks like a raised transverse ridge (Fig. $3 \mathrm{C})$. Anterolaterally with respect to the lateral gastric teeth are situated 15 accessory teeth with mostly rounded tips (Fig. 3D). The dorsal part of the cardiopyloric valve is triangular and has two teeth pointed toward the anterior. Laterally of these teeth there are brush-like setae (Fig. 3E,F).

\section{DISCUSSION}

The two mangrove species Heloecius cordiformis (Milne Edwards, 1837) and Ucides occidentalis (Ortmann, 1897) as well as their phylogenetic placement have been discussed controversially during the last decades. The genus Ucides was placed within the Gecarcinidae for a long time since its description. Due to the swollen branchial regions, which were considered as the prime character of the Gecarcinidae, Chace \& Hobbs (1969), correctly pointed out that this character is correlated with the terrestrial life and, therefore, is more of an ecological feature than an indicator of phylogenetic relationships. They stated that all other characters, especially those as the mouthparts and legs, were more similar to ocypodids than to gecarcinids and moved the genus to the OcypodidaeThe relationships within this family remained, however, uncertain. Türkay (1970) agreed with the conclusions of the former authors and kept the genus in the ocypodids. When re-examining the taxonomic position of the Australian mangrove crab genus Heloecius, Türkay (1983) discovered the coxosternal position of the male genital openings of this genus and therefore removed it from the relationship with the purely sternotreme genus 

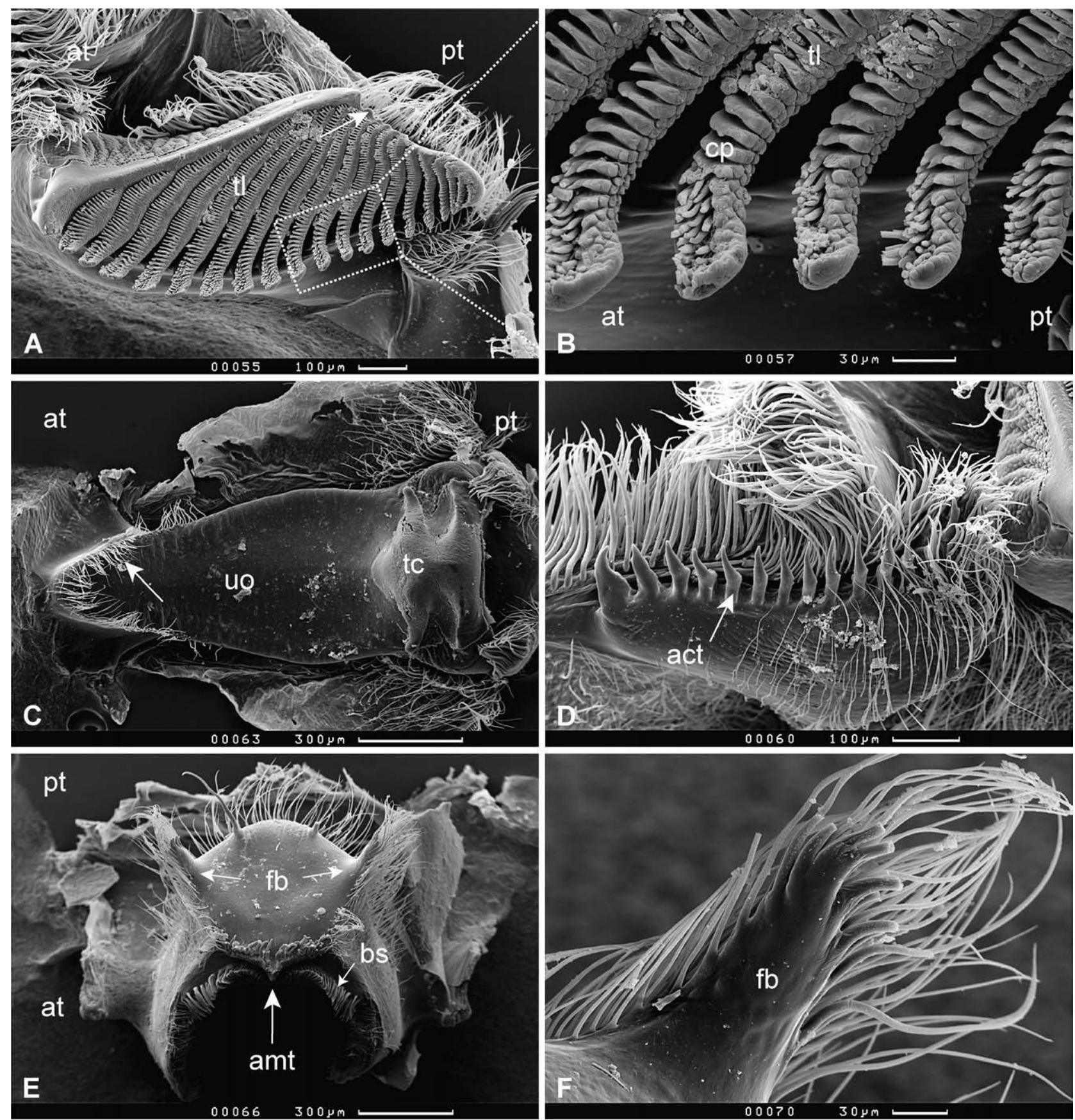

Fig. 1. Gastric teeth of Dotilla fenestrata, SMF 9109, (A) Dorsomedian view on the lateral teeth. (B) Section of Figure 1A, transverse lamellae of the lateral teeth. (C) Ventral view on the dorsomedian tooth. (D) Lateral view on the accessory teeth. (E) Anterodorsal view on the cardiopyloric valve. (F) Enlarged view of the fringed bulges. alt, anterolateral teeth; amt, anteromedian tooth; at, anterior; bs, brush-like setae; cp, comb-like processes; fb, fringed bulges; pt, posterior; tc, teeth cusps; tl, transverse lamellae; uo, urocardiac ossicle; wp, wing-like plates.

$U c a$, with which the former, indeed, shares a superficial similarity, and accommodated it in a separate subfamily, the Heloecinae. This conclusion was later confirmed by Fielder and Greenwood (1985) on the basis of larval morphology. Türkay (1983) also discussed similarities and differences between Heloecius and Ucides and showed that the latter is more advanced as to sternotremy based on the fact that the seventh and eighth sternite meet over the base of the penis, but still the shape of the hind part of the sternum is very similar in both genera, as is the general shape of the male pleopod. He therefore included Ucides tentatively in the Heloecinae.

$\mathrm{Ng}$ et al. (2008) recognized Heloecius and Ucides as belonging to distinct families [Heloeciidae (Milne Edwards, 1852) and Ucididae (Śtevcic, 2005)] within 

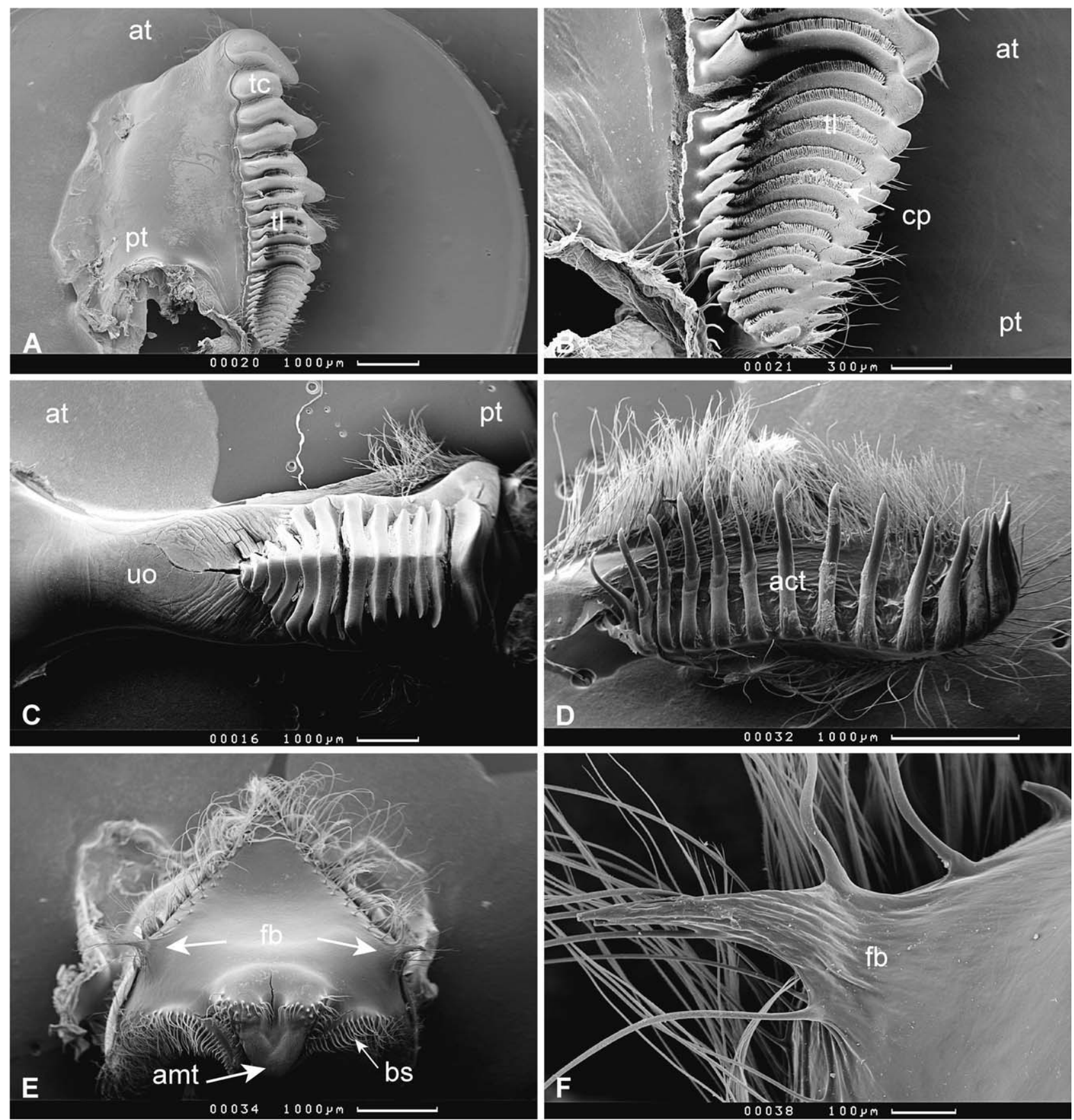

Fig. 2. Gastric teeth of Ucides occidentalis, SMF 4139, (A) dorsal view on the lateral teeth. (B) Dorsal view on the posterior half of the lateral teeth with transverse lamellae. (C) Dorsal view on the dorsomedian tooth. (D) Lateral view on the accessory teeth. (E) Anterodorsal view on the cardiopyloric valve. (F) Enlarged view of the fringed bulges.

the Ocypodoidea (Rafinesque, 1815). Concerning the Dotillidae, molecular data from Kitaura et al. (2002) and Schubart et al. (2006) suggest a closer relationship of Dotilla (Ocypodidae) to the Gecarcinidae, Plagusiidae, and Sesarmidae.

Furthermore, the results of our study indicate that the general conclusion of a nonadaptation of foregut structures to the described food preferences needs more differentiation. This means that the morphology of the foregut ossicles and the attached gastric teeth have to be evaluated separately. The comparison of the gastric teeth of at least four different taxa and their morphological similarities suggests a possible correlation to a filter/suspension, herbivore or carnivore feeding behavior, whereas the foregut ossicles appear not to be affected by the food preference. However, this does not exclude the that gastric teeth morphology may be used for taxonomic 

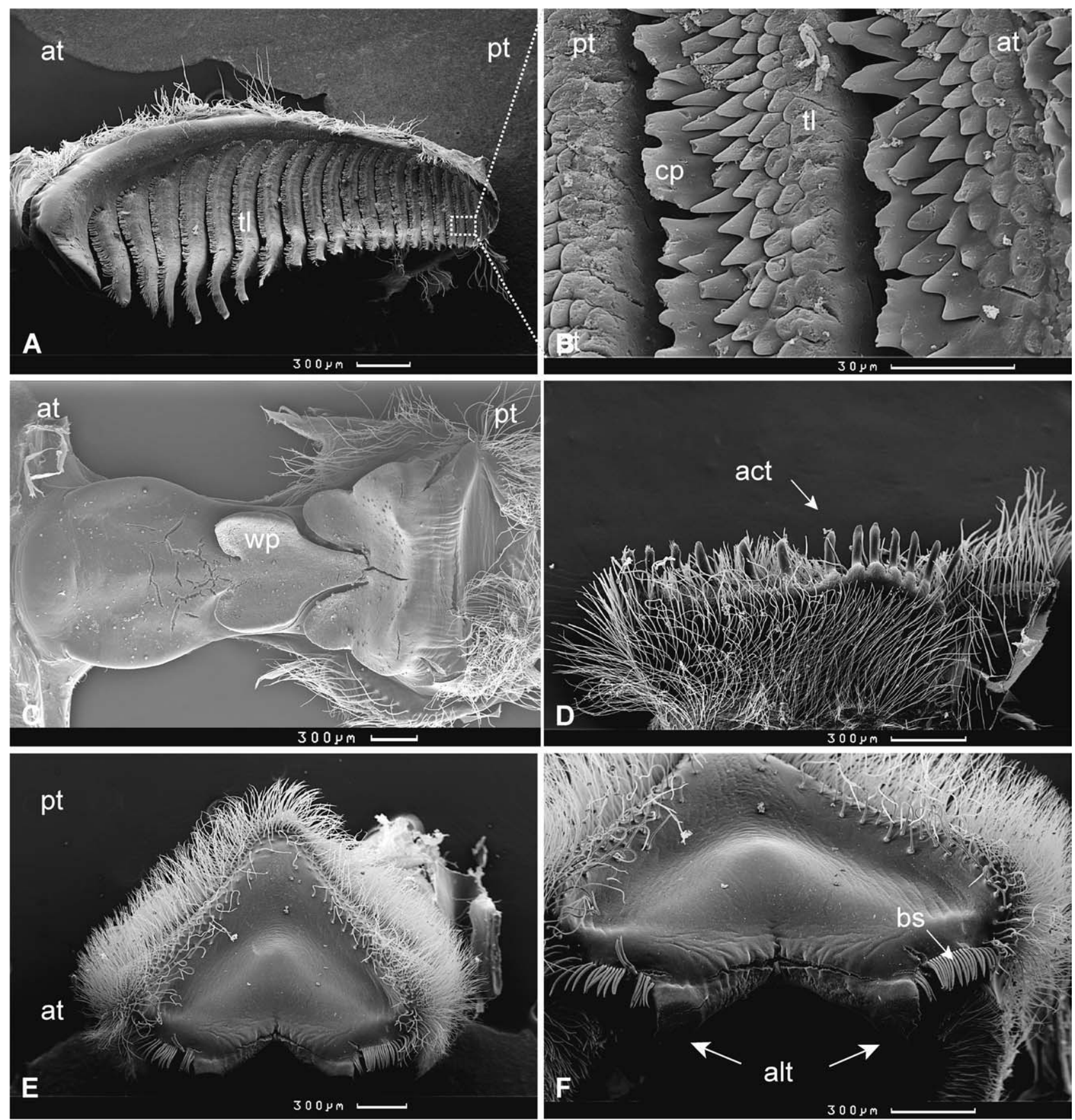

Fig. 3. Gastric teeth of Heloecius cordiformis, SMF 921, (A) dorsal view on the lateral teeth. (B) Ausschnitt von Fig. 3A, Transverse lamellae of the lateral teeth. $(\mathbf{C})$ Ventral view on the dorsomedian tooth. (D) Lateral view on the accessory teeth. (E) Dorsal view on the cardiopyloric valve. (F) Anterodorsal view on the cardiopyloric valve.

studies of closely related taxa (e.g., Naderloo and Schubart, 2010; Naderloo et al., 2010).

The present study indicates that in $H$. cordiformis and D. fenestrata, as well as in Mictyris longicarpus and Uca (Minuca) rapax (Brösing, 2010), the lateral gastric teeth are similarly shaped because of the absence of lateral teeth cusps and the presence of transverse lamellae with comb-like structures on the anterior margin. All of the above-mentioned species are suspension feeders (Table 2), which all occur at tropi- cal and subtropical beaches. However, Maitland (1990) described Heloecius also to have well-developed mandibles for feeding on plants or animal material. This raises the question: why Heloecius is able to feed on animals and plants with gastric teeth structures suitable for filter feeding? Or is the food preference independent of the structure of these teeth?

An unclear structure of the cardiopyloric valve is found in specimens of $D$. fenestrata and U. occidentalis. Both have fringed bulges at the dorsolateral mar- 
TABLE 2. Brachyuran food preferences

\begin{tabular}{|c|c|c|c|c|}
\hline Taxa & Herbivore & Carnivore & $\begin{array}{l}\text { Suspension } \\
\text { Filter feeders }\end{array}$ & References \\
\hline Dotillidae Stimpson, 1858 & & & $\checkmark$ & $\begin{array}{l}\text { Warner, 1977; Grahame,1983; } \\
\text { Henmi and Koga, } 2009\end{array}$ \\
\hline Heloeciidae Milne Edwards, 1852 & $\checkmark$ & $\checkmark$ & $\checkmark$ & Griffin, 1968; Maitland, 1990 \\
\hline Mictyridae Dana, 1851 & & & $\checkmark$ & Quinn, 1980, 1986 \\
\hline Genus $U c a$ (s. str.) & & & $\checkmark$ & Crane, 1975; Robertson and Newell, 1982 \\
\hline Ucididae Števcic, 2005 & $\checkmark$ & & & $\begin{array}{l}\text { Nordhaus, 2003, Nordhaus and Wolff, 2007; } \\
\quad \text { Nordhaus et al., } 2006\end{array}$ \\
\hline Genus Cardisoma & $\checkmark$ & $\checkmark$ & & Herreid II, 1963, Greenaway and Raghaven, 1998 \\
\hline Sesarmidae Dana, 1851 & $\checkmark$ & & & $\begin{array}{l}\text { Emmerson and McGwynne, 1992; Micheli, } \\
\text { 1993; Ng and Sivasothi, } 1999\end{array}$ \\
\hline
\end{tabular}

gin that are not present in $H$. cordiformis. This means that the two more ancestral genera Ucides and Heloecius may not be closely related, and the sterna structures are plesiomorphies rather than synapomorphies. Our results also show that the gastric teeth of $U$. occidentalis are similar to the structures described for Cardisoma armatum and Pseudosesarma moeschi (Brösing, 2010). They all have clear transverse lamellae on the lateral gastric teeth and at least in $P$. moeschi, there are also comb-like structures on the anterior margin of the transverse lamellae. Furthermore, the dorsomedian teeth of $U$. occidentalis, C. armatum, and $P$. moeschi consist of transverse teeth cusps. On the basis of these results, we think that the structures of the gastric teeth (the lateral teeth and the dorsomedian tooth) of $U$. occidentalis do not support the removal of this genus, and the family Ucididae, from the Grapsoidea, to which the Gecarcinidae and Sesarmidae belong, and its inclusion into the Ocypodoidea.

Our results also show that the teeth of the brachyuran gastric mill have a comparatively stable ground pattern, which does not exclude adaptation to specific food preferences or resources.

\section{ACKNOWLEDGMENTS}

The authors thank Prof. Dr. Katsushi Sakai for helpful discussions and comments. The authors also thank Dr. Fiege and Mrs. Tritz (Senckenberg Forschungsinstitut und Naturmuseum Frankfurt) for assistance in using the scanning electron microscope. For the critical review of the English language the authors thank Mrs. Goodwin, GRADEGoethe Graduate Academy, Goethe University Frankfurt am Main.

\section{LITERATURE CITED}

Abele LG, Felgenhauer BE. 1986. Phylogenetic and phenetic relationships among the lower Decapoda. J Crustacean Biol $6: 385-400$

Allardyce BJ, Linton SM. 2010. Functional morphology of the gastric mill of carnivorous, omnivorous, and herbivorous land crabs. J Morphol 271:61-72.

Alves ST, Abrunhosa FA, Lima JF. 2010. Foregut morphology of Pseudothelphusidae and Trichodactylidae (Decapoda: Bra- chyura) from northeastern Pará, Brazil. Zoologia (Curitiba, Impresso) 27:228-244.

Brösing A. 2010. Recent developments on the morphology of the brachyuran foregut ossicles and gastric teeth. Zootaxa 2510:1-44.

Brösing A. 2002. Die Magenstrukturen der Brachyura (Crustacea, Decapoda), Morphologie und phylogenetische Bedeutung [dissertation]. Germany: Humboldt University Berlin, 260 p. Available from: Digital dissertation.

Brösing A, Richter S, Scholtz G. 2002. The foregut-ossicle system of Dromia wilsoni, Dromia personata and Lauridromia intermedia (Decapoda, Brachyura, Dromiidae), studied with a new staining method. Arthropod Struct Dev 30:329-338.

Brösing A, Richter S, Scholtz G. 2007. Phylogenetic analysis of the Brachyura (Crustacea, Decapoda) based on characters of the foregut with establishment of a new taxon. J Zoo Syst Evol Res 45:20-32.

Caine EA. 1975. Feeding and masticatory structures of selected Anomura (Crustacea). J Exp Mar Biol Ecol 18:277-301.

Ceccaldi HJ. 1997. Anatomy and physiology of the digestive system. In: D'Abramo LR, editor. Crustacean Nutrition. Advances in World Aquaculture, Vol. 6. Baton Rouge, LA: The World Aquaculture Society. pp 261-291.

Chace FA, Hobbs HH. 1969. The freshwater and terrestrial decapod crustaceans of the West Indies: with special reference to Dominica. U S Natl Mus Bull 292:1-258.

Crane J. 1975. Fiddler Crabs of the World. Princeton, NJ: Princeton Univ. Press.739 pp.

Emmerson WD, McGwynne LE. 1992. Feeding and assimilation of mangrove leaves by the crab Sesarma meinerti de Man in relation to leaf-litter production in Mgazana, a warm-temperate southern African mangrove swamp. J Exp Mar Biol Ecol 157:41-53.

Felgenhauer BE. 1992. Internal anatomy of the decapoda: An overview. In: Harrison FW, editor. Microscopic Anatomy of Invertebrates, Decapod Crustacea, Vol. 10. New York: WileyLiss. pp 45-75.

Felgenhauer BE, Abele LG. 1983. Phylogenetic relationships among shrimp-like decapods. In: Schram FR, editor. Crustacean Phylogeny. Crustacean Issues, Vol. 1. Rotterdam: Balkema. pp 291-311.

Felgenhauer BE, Abele LG. 1985. Feeding structures of two atyid shrimps, with comments on caridean phylogeny. J Crustacean Biol 5:397-419.

Felgenhauer BE, Abele LG. 1989. Evolution of the foregut in the lower Decapoda. In: Felgenhauer BE, editor. Functional Morphology of Feeding and Grooming in Crustacea. Rotterdam: Balkema. pp 205-219.

Fielder DR, Greenwood JG. 1985. The systematic position of Heloecius cordiformis (H. Milne Edwards, 1837) (Decapoda, Ocypodidae) as revealed by larval morphology. Crustaceana 48:244-248.

Grahame J. 1983. Adaptive aspects of feeding mechanisms. Environ Adapt 8:65-107.

Greenaway P, Raghaven S. 1998. Digestive strategies in two species of leaf-eating land crabs (Brachyura: Gecarcinidae) in a rain forest. Physiol Biochem Zool 71:36-44. 
Griffin DJ. 1968. Social and maintenance behaviour in two Australian ocypodid crabs (Crustacea: Brachyura). J Zool London 156:291-305.

Growns IO, Richardson AM. 1990. A comparison of the gastric mills of nine species of parastacid crayfish from a range of habitats, using multivariate morphometrics (Decapoda, Astacoidea). Crustaceana 58:33-44.

Henmi Y, Koga H. 2009. Growth and reproduction of the intertidal dotillid crab Ilyoplax deschampsi. J Crustacean Biol 29:516-522.

Herreid CF. 1963. Observations on the feeding behavior of Cardisoma guanhumi (Latreille) in Southern Florida. Crustaceana 5:176-180.

Hilgendorf F. 1869. Crustaceen. In: Baron Carl Claus von der Decken's Reisen in Ost-Afrika in den Jahren 1859-1865. Band 3. Wissenschaftlicher Theil, Wissenschaftliche Ergebnisse. Abt. 1. Säugethiere, Vögel, Amphibien, Crustaceen, Mollusken und Echinodermen. Leipzig: Winter. p. 69-102, Taf. 1-6.

Huespe AV, Gómez-Simes E, Pastor-de-Ward CT. 2008. Gastric mill morphology in the genus Cyrtograpsus (Crustacea: Decapoda: Grapsoidea: Varunidae). J Mar Biol Assoc UK 88:311-319.

Kitaura J, Wada K, Nishida M. 2002. Molecular phylogeny of grapsoid and ocypodoid crabs with special reference to the genera Metaplax and Macrophthalmus. J Crustacean Biol 22:682-693.

Kropp RK. 1986. Feeding biology and mouthpart morphology of three species of coral gall crabs (Decapoda: Cryptochiridae). J Crustacean Biol 6:377-384.

Maitland DP. 1990. Feeding and mouthpart morphology in the semaphore crab Heloecius cordiformis (Decapoda: Brachyura: Ocypodidae). Mar Biol 105:287-296.

Maynard DM, Dando MR. 1974. The structure of the stomatogastric neuromuscular system in Callinectes sapidus, Homarus americanus and Panulirus argus (Decapoda, Crustacea). Phil Trans Royl Soc London, B 268, 161-220.

Meiss DE, Norman RS. 1977. A comparative study of the stomatogastric system of several decapod Crustacea, I. Skeleton. J Morp 152, 21-54.

Micheli F. 1993. Feeding ecology of mangrove crabs in North Eastern Australia: Mangrove litter consumption by Sesarma messa and Sesarma smithii. J Exp Mar Biol Ecol 171:165-186.

Milne Edwards H. 1837. Histoire Naturelle des Crustacés, Comprenant L'anatomie, la Physiologie et la Classification de ces Animaux. Paris: Librairie Encyclopédique de Roret. 2:532 p.

Milne Edwards H. 1852. De la famille des ocypodides (Ocypodidae). Second Mémoire. In: Observations sur les affinités zoologiques et la classification naturelle des Crustacés. Ann Sci Nat 18:128-166, pls 3, 4.

Naderloo R, Schubart CD. 2010. Description of a new species of Parasesarma (Crustacea; Decapoda; Brachyura; Sesarmidae) from the Persian Gulf based on morphological and genetic characteristics. Zool Anz Jena 249:33-43.

Naderloo R, Türkay M, Chen HL. 2010. Taxonomic revision of the wide-front fiddler crabs of the Uca lactea group (Crustacea: Decapoda: Brachyura: Ocypodidae) in the Indo-West Pacific. Zootaxa 2500:1-38.
Ng PK, Guinot D, Davie PJ. 2008. Systema Brachyurorum: Part I. An annotated checklist of extant brachyuran crabs of the world. Raffles Bull Zool 17:1-286.

Ng PK, Sivasothi N. 1999. A Guide to the Mangroves of Singapore I: The Ecosytem and Plant Diversity. Singapore Science Centre: Singapore.166 p.

Nordhaus I. 2003. Feeding Ecology of the Semi-Terrestrial Crab Ucides Cordatus Cordatus (Decapoda: Brachyura) in a Mangrove Forest in Northern Brazil. [dissertation]. Bremen: Universität Bremen, Zentrum für Marine Tropenökologie (ZMT).203 p.

Nordhaus I, Wolff M. 2007. Feeding ecology of the mangrove crab Ucides cordatus (Ocypodidae): food choice, food quality and assimilation efficiency. Mar Biol 151:1665-1681.

Nordhaus I, Wolff M, Diele K. 2006. Litter processing and population food intake of the mangrove crab Ucides cordatus in a high intertidal forest in northern Brazil Estuarine. Coastal Shelf Sci 67:239-250.

Ortmann A. 1897. Carcinologische Studien. Zool Jahrb Abt Syst Oekol Geogr Tiere 10:258-372.

Quinn RH. 1980. Mechanisms for obtaining water for flotation feeding in the soldier crab, Mictyris longicarpus Latreille, 1806 (Decapoda, Mictyridae). J Exp Mar Biol Ecol 43:49-60.

Quinn RH. 1986. Experimental studies of food ingestion and assimilation of the soldier crab, Mictyris longicarpus Latreille (Decapoda, Mictyridae). J Exp Mar Biol Ecol 102:167-181.

Rafinesque CS. 1815. Analyse de la nature, ou tableau de l'univers et des corps organisés. Jean Barravecchia, Palermo, $224 \mathrm{p}$.

Robertson JR, Newell SY. 1982. Experimental studies of particle ingestion by the sand fiddler crab Uca pugilator (Bosc). J Exp Mar Biol Ecol 59:1-21.

Sakai K, Türkay M, Yang SL. 2006. Revision of the Helice/Chasmagnathus complex (Crustacea: Decapoda: Brachyura). Abhandlungen der Senckenbergischen Naturforschenden Gesellschaf 565:1-76.

Schubart CD, Cannicci S, Vannini M, Fratini S. 2006. Molecular phylogeny of grapsoid crabs (Decapoda, Brachyura) and allies based on two mitochondrial genes and a proposal for refraining from current superfamily classification. J Zoolog Syst Evol Res 44:193-199.

Stevcic Z. 2005. The reclassification of brachyuran crabs (Crustacea: Decapoda: Brachyura). Natura Croatica 14 (Suppl 1): $1-159$.

Türkay M. 1970. Die Gecarcinidae Amerikas, Mit einem Anhang über Ucides Rathbun (Crustacea: Decapoda). Senckenbergiana Biol 51:333-354.

Türkay M. 1983. The systematic position of an Australian mangrove crab Heloecius cordiformis (Crustacea: Decapoda: Brachyura). Mem Australian Mus 18:107-111.

Warner GF. 1977. The Biology of Crabs. London: Elek Science.202 p.

Yang SL. 1986. The diagnostic value of gastric mill's construction as taxonomic character on the classification of crabs (Brachyura: Crustacea). Acta Zootaxonomica Sinica 11:151-159. 